\title{
The Distribution of the Heavy Metals in Soil Sample Along Blue Nile During overflow Season
}

\author{
Magdi H. Saad ${ }^{1,2}$ \\ ${ }^{1}$ Department of Physics, Faculty of Science, Taibah University - Yanbu Branch, KSA \\ ${ }^{2}$ Department of Physics, Sudan University of Science \& Technology, Khartoum, SUDAN \\ Correspondence: Magdi H. Saad, Department of Physics, Taibah University, Collage of Science at Yanbu, KSA. \\ Tel: 966-501-083-715. E-mail: miligi2000@gmail.com
}

Received: December 26, 2017

Accepted: January 4, 2018

Online Published: January 30, 2018

doi:10.5539/apr.v10n1p19

URL: https://doi.org/10.5539/apr.v10n1p19

\begin{abstract}
The research cared out to calculate the heavy metals deposition for the soil of the Blue Nile along the edges of two sides, starting from the Sudan Ethiopia border end to the Khartoum state in Tuti Island. The samples were analyzed by inductively coupled plasma mass spectrometry (ICP-MS) technique. The results show that there is a significant difference for most of the concentration of the elements deposition on two sides of the Blue Nile outside of Nile channel for that area which covered by water after the overflow. Heavy metals $\mathrm{Cr}, \mathrm{Fe}, \mathrm{Co}, \mathrm{Cu}$, and $\mathrm{Zn}$ concentration deposition are increased in the direction of the water to Khartoum, while $\mathrm{Ni}$ and $\mathrm{Pb}$ concentrations are decreased in the same direction. $\mathrm{K}, \mathrm{Ca}, \mathrm{Ti}, \mathrm{Mn}, \mathrm{Br}, \mathrm{Rb}, \mathrm{Sr}$, and $\mathrm{Zr}$ heavy metal concentrations are varied but in general remains equals.
\end{abstract}

Keywords: Blue Nile, Heavy Metal, Soil, overflow, ICP-MS

\section{Introduction}

The most critical springs of water for every single living thing are the rivers, as well as lakes, oceans, water catchments and underground water. Rivers are imperative to people and different living beings as they are basic assets for the living. River Nile form the biggest streams on the planet and it is quite long in such away that it is defenseless to numerous contaminations inside the capital Khartoum, particularly at the juncture of the White Nile and Blue Nile (called Al-Mugran) where it finds numerous contamination activities. This is in addition to the likelihood of substantial metal contaminants as has recently been studied by Sulieman et al. (2017).

The total length of the Blue Nile 1,450 kilometers, of which 800 kilometers are inside Ethiopia (Central Statistical Agency website, 2009). Figure 1. The maximum flow of the Blue Nile occur in rainy season carry an amount of soil from the Ethiopian Highlands and carry it downstream as a dummy, makes the water dark brown or almost black (Dinknesh, 2015). The Blue Nile was a major source of the flooding of the Nile and its most significant tributary of the Nile and almost more than half of the Nile's stream flow (Mohamed Helmy, 2012). Soil that enriched with heavy metals can cause a reverse impact on the people by ingestion inhalation, and skinny contact. Accumulated soil by heavy metals can also cause potential long-term hazards to plants and animals as well as humans that take these plants. (Singh \& Kumar, 2006).

The presence of heavy metals in the Blue Nile deposit is affected by the particle size of the sediments, this actually attributed to co-precipitation, sorption, and complexing of metals on particle surfaces and coatings (Walling, 1992; Sakai et al., 1986; Krishna \& Govil, 2008). There for a need for re-estimate the heavy metals in the Blue Nile adjacent soil sediment to ensure environmental sustainability for human and animal (Senesi, 1999; Saad, 2017).

\section{Sampling and Samples Preparation}

For most clinical methods using ICP-MS, there is a relatively simple and quick sample prep process. The main component of the sample is an internal standard, which also serves as the diluent. This internal standard consists primarily of deionized water, with nitric or hydrochloric acid, and Indium and/or Gallium.

Samples were taken from the surface soil (10 cm depth) of the Blue Nile, and $10 \mathrm{~m}-1 \mathrm{~km}$ far from the bank the Blue Nile for areas that covered by the flood. The cities were sampled are taken in Khartoum, Wad Medani, Singa and Ed Damazin, Figure 2. Gee 1986. Samples were digested by EPA-3050 method. EPA 1996. 0.5gr of well-milled 
samples dried by air in the microwave oven pipes, and $10 \mathrm{ml}$ of 1:1 HNO3 was added and covered with a watch glass. Samples were heated for 20 minutes below boiling point and then cool down. For extraction, digested samples were transferred quantitatively into $50 \mathrm{ml}$, volume was completed by using distilled water. Samples were filtered and stored in polyethylene bottles at a low temperature until analysis.

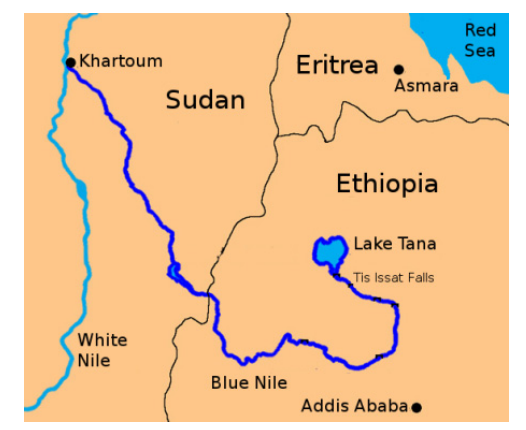

Figure 1. Blue Nile from the source in Ethiopia to destination in Khartoum
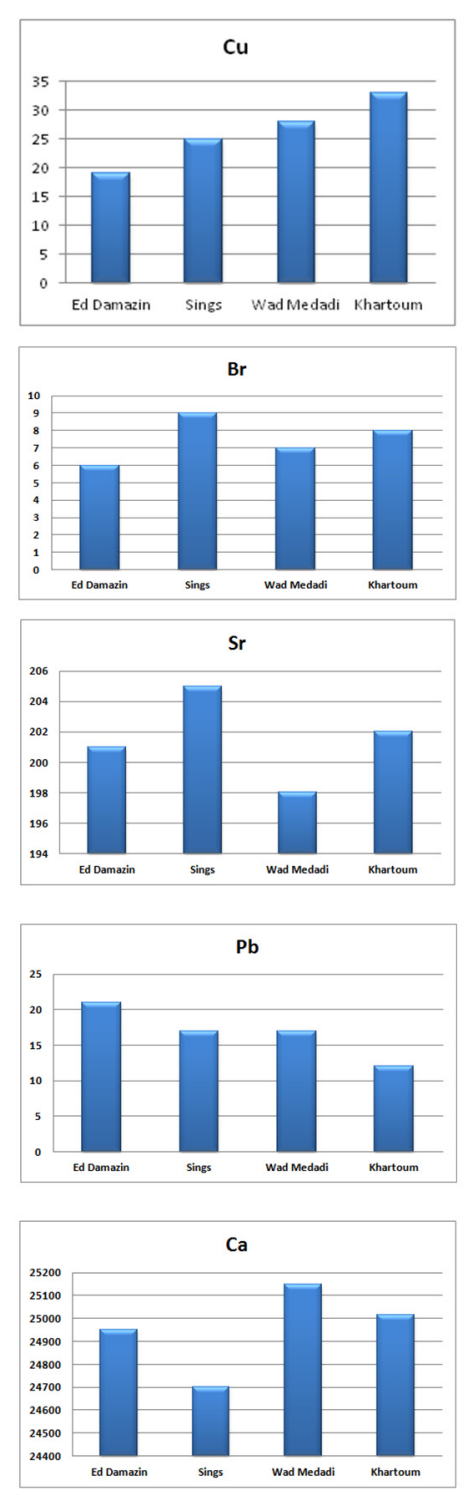
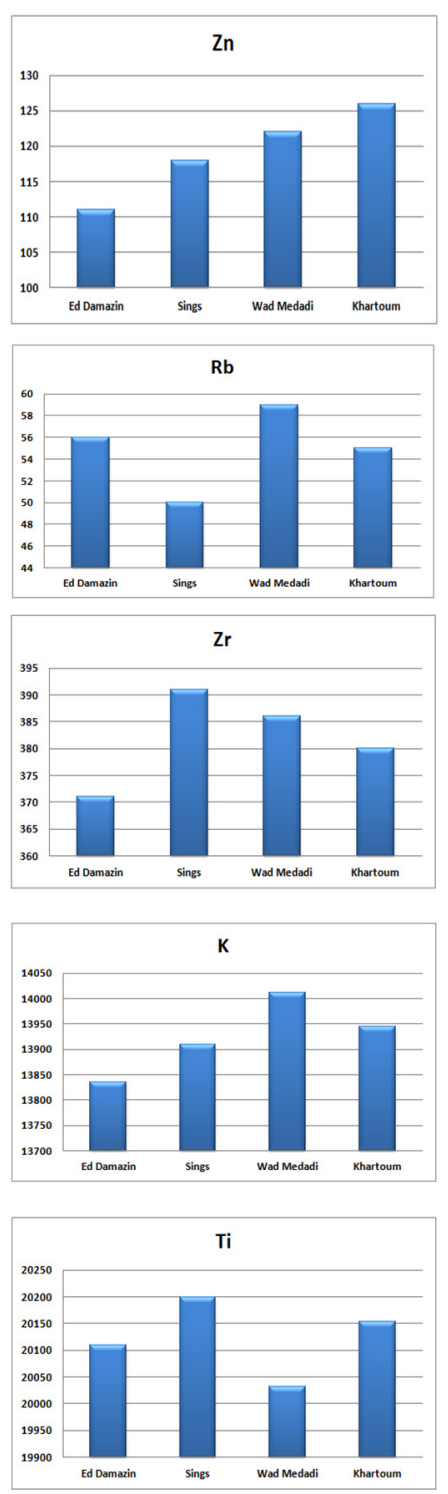

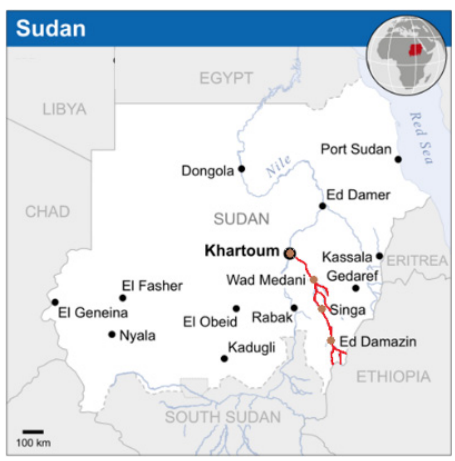

Figure 2. Blue Nile with red color \& Cities of the samples with brown color
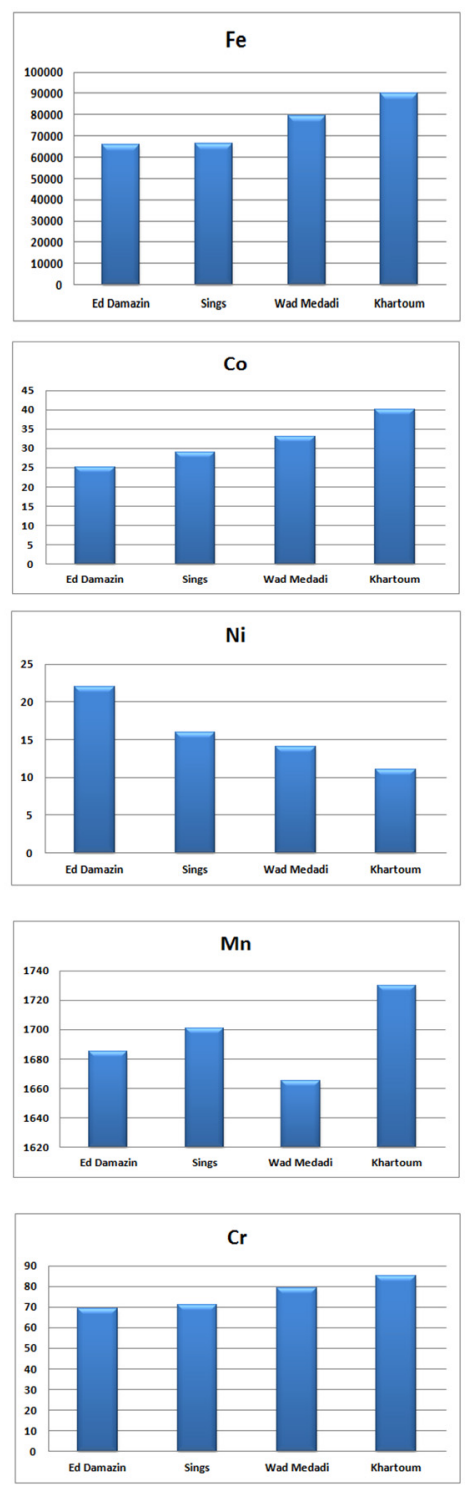

Figure 3. The concentration of the Heavy elements $\mathrm{mg} / \mathrm{kg}$ 


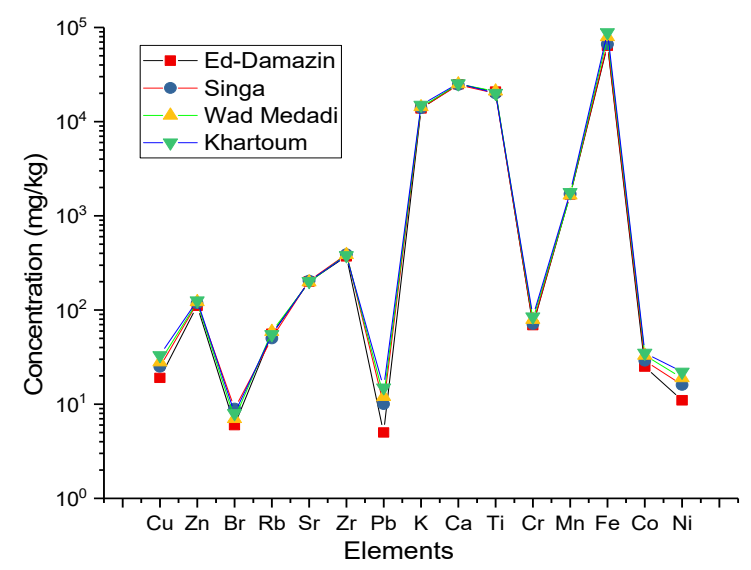

Figure 4. Distribution of the concentration for the heavy metals in four cities along the Blue Nile in Sudan

\section{Results Discussion}

Due to the variation of the soil topography composition between Sudan and Ethiopia, this varies from the rocky mountain in Ethiopia and mud/clay in Sudan leads to the difference of elements concentration and types. The percentage of particles size and organic matter is higher in wet than dry seasons in soil samples Muna 2014. The relationships between heavy metals and organic matter provided interesting information on heavy metal sources and pathways Thorne 1981. Therefore I have conducted an experimental investigation of the heavy metals in four main cities in Sudan that are residing along the Blue Nile. This investigation aimed at the measurement of the concentration of these metals. The following I will demonstrate and discuss the results of these measurements in each city starting from the city closer to the Ethiopian-Sudanese boarder and ending with the capital of Sudan, Khartoum city, in the center of Sudan.

In Ed-Damazin city where the nature of the soil is of a rocky stone type, the highest element concentration is 63970 $\mathrm{mg} / \mathrm{kg}$ for $\mathrm{Fe}$, while the least element concentration is $5 \mathrm{mg} / \mathrm{kg}$ for Pb (Table 1 and Figure 3). The variation in the concentration of other elements lie between these two extremes for $\mathrm{Fe}$ and $\mathrm{Pb}$ as can clearly be seen from Table 1 . Similarly, Singa city demonstrates the most element concentration of $66313 \mathrm{mg} / \mathrm{kg}$ for $\mathrm{Fe}$ and the least concentration of $9 \mathrm{mg} / \mathrm{kg}$ for Br. This indicates that the Fe concentration in Singa city has increased from its value in Ed-Damazin due to the element precipitation along the river flow line caused by the quite flow of water. The precipitation effect has also resulted in a further reduction in Fe concentration $(79451 \mathrm{mg} / \mathrm{kg}$ Table 1 and Figure 3) in Wad Medani city which is located after Singa along the line flow of the Blue Nile. However the lowest element concentration in Wad Medani is for $\mathrm{Br}$ at $7 \mathrm{mg} / \mathrm{kg}$. It is evident that Wad-Madani and Singa agree in the element $\mathrm{Br}$ which has lower concentration. In contrast, Ed-Damazin has lowest concentration for the element $\mathrm{Pb}$. This discrepancy could be associated with the geological nature of the soil in these cities since Wa-Madina and Singa have clay type soil while Ed-Mazine soil if rocky. For Khartoum city, which lies further down the direction of the Nile flow, and which has a muddy soil, the highest element concentration is again for Fe at $88768 \mathrm{mg} / \mathrm{kg}$, while the lowest element concentration is $\mathrm{Br}$ at $8 \mathrm{mg} / \mathrm{kg}$.

An overall view of the concentration distribution of the whole set of elements in the four cities is illustrated in Figure 4. Interestingly, all cities agree in the maximum concentration for Fe. The highest Fe concentration could be attributed to the lower PH level in water (Sulieman, 2017; GTM, 2007). The cities also agree the lowest element concentration for $\mathrm{Pb}$ and $\mathrm{Br}$. It is worth noting that the element concentration nearly oscillates in a logarithmic scale as shown in Figure 4. Again this could suggest that the variation in the geological nature of the soil in these cities has led to variation in element deposition strength, resulting in the pattern shown in Figure 4.

More specifically the results in Figure 3 and 4 indicated that the average values of the heavy metals concentration of $\mathrm{Cr}, \mathrm{Fe}, \mathrm{Co}, \mathrm{Cu}$, and $\mathrm{Zn}$ were 76, 74625.5, 30.5, 26.25 and $119.25 \mathrm{mg} / \mathrm{kg}$, respectively, while the percentageincrease in these elements from Ed-Mazine to Khartoum is 19, 28, 29, 42, and $12 \%$ respectively. The heavy metals that were decreased in the concentration were $\mathrm{Ni}$ and $\mathrm{Pb}$ with average of 17 and $14.5 \mathrm{mg} / \mathrm{kg}$, respectively. The percent of the reduction is $50 \%$ and $57 \%$, respectively. For $\mathrm{K}, \mathrm{Ca}, \mathrm{Ti}, \mathrm{Mn}, \mathrm{Br}, \mathrm{Rb}, \mathrm{Sr}$, and $\mathrm{Zr}$ heavy metals the average concentrations are 14287, 25020.25, 20483.25, 1705.25, 7.5, 55, 201.5 and $382 \mathrm{mg} / \mathrm{kg}$ respectively, and having almost the same order of magnitude for the change in concentration from Ed-Mazine towards Khartoum. 
Table 1. The concentration of heavy Elements in soil samples $(\mathrm{mg} / \mathrm{Kg})$

\begin{tabular}{ccccccccccccccccc}
\hline location & \multicolumn{11}{c}{ Heavy metals concentration $(\mathrm{mg} / \mathrm{Kg})$} \\
\hline & $\mathrm{Cu}$ & $\mathrm{Zn}$ & $\mathrm{Br}$ & $\mathrm{Rb}$ & $\mathrm{Sr}$ & $\mathrm{Zr}$ & $\mathrm{Pb}$ & $\mathrm{K}$ & $\mathrm{Ca}$ & $\mathrm{Ti}$ & $\mathrm{Cr}$ & $\mathrm{Mn}$ & $\mathrm{Fe}$ & $\mathrm{Co}$ & $\mathrm{Ni}$ \\
Ed Damazin & 19 & 111 & 6 & 56 & 201 & 371 & 5 & 13835 & 24950 & 20780 & 69 & 1685 & 63970 & 25 & 11 \\
Singa & 25 & 118 & 9 & 50 & 205 & 391 & 10 & 13909 & 24569 & 19968 & 71 & 1701 & 66313 & 29 & 16 \\
Wad Medadi & 28 & 122 & 7 & 59 & 198 & 386 & 12 & 14359 & 25147 & 21031 & 79 & 1655 & 79451 & 33 & 19 \\
Khartoum & 33 & 126 & 8 & 55 & 202 & 380 & 15 & 15045 & 25415 & 20154 & 85 & 1780 & 88768 & 35 & 22 \\
Average: & 26.3 & 119.3 & 7.5 & 55.0 & 201.5 & 382.0 & 14.5 & 14287.0 & 25020.3 & 20483.3 & 76.0 & 1705.3 & 74625.5 & 30.5 & 17.0 \\
\hline
\end{tabular}

\section{References}

Central Statistical Agency website. (2009). National Statistics (Abstract) Climate, 2008, Table A.1.

Dinknesh Ethiopia Tour. (2015). Archived from the original. "The Blue Nile: Its Origin, Falls, and Gorge".

Elsanabary, M. H. M. M. (2012). Teleconnection, Modeling, Climate Anomalies Impact and Forecasting of Rainfall and Streamflow of the Upper Blue Nile River Basin (Doctoral dissertation, University of Alberta).

Gee, G. W., Bauder, J. W., \& Klute, A. (1986). Particle-Size Analysis, Methods of Soil Analysis, Part 1. Physical and Mineralogical Methods, Soil Since Society of America. Inc., Madison, WIS, USA.

GTM-24, Geotechnical Test Method. (Ed.) (2007). Test Method for Determination of pH Value of Water or Soil by $\mathrm{pH}$ Meter. New York, Department of Transportation.

Saad, M. H. Evaluation of the concentration of the trace elements in soil samples from rivers in the Khartoum State in Sudan. International Journal of Scientific \& Engineering Research, 8(2).

Senesi, G. S., Baldassarre, G., Senesil, N., \& Radina, B. (1999). Chemosphere. Analytica Chimica Acta, 39, 343.

Shumo, M. I., Taha, K. K., Ahemad, A. Y., \& Abdullah, M. P. (2014). Accumulation of Heavy Metals in the Floodplains along River Nile, White and Blue Niles at Dry and Rainy Season in the Khartoum city, Sudan. Journal of Applied and Industrial Sciences, 2(5), 226-233.

Sulieman, M. M., Elfaki, J. T., Adam, M. M., Dafalla, M. S., Ali, S. H., Ahmed, H. M., \& Ali, M. E. (2017). Assessment of heavy metals contamination in the Nile River water and adjacent sediments: A case study from Khartoum City and Nile River State, Sudan.

Thorne, L. T., \& Nickless, G. (1981). The relationbet ween heavy metals and particle size fractions within the seven estuary (UK) inter-tidal sediments. Sci. Total Environ., 19, 207-213.

US Environmental Protection Agency (EPA). (Ed.) (1996). Acid digestion of soils: 3050 Method B. Washington, District of Columbia.

Walling, D. E., Quine, T. A., \& He, Q. (1992). Investigating contemporary rates of floodplain sedimentation. In P. A. Carling, \& G. E. Petts (Eds.), Lowland floodplain rivers (pp. 165-184). Wiley.

\section{Copyrights}

Copyright for this article is retained by the author(s), with first publication rights granted to the journal.

This is an open-access article distributed under the terms and conditions of the Creative Commons Attribution license (http://creativecommons.org/licenses/by/4.0/). 